\title{
Pre-service Teachers' Perceptions and Views towards Instructional Technologies: A Study Based Upon Synectic Model
}

\author{
DOI: $10.26466 /$ opus. 868978
}

\author{
Tuğba Yanpar Yelken* - Seda Baysal ** \\ * Prof. Dr., Mersin University, Faculty of Education, Mersin/Turkey \\ E-Mail: tyanpar@gmail.com \\ ORCID: 0000-0002-0800-4802 \\ ** Instructor, Kahramanmaraş Sütçü İmam University, FLS, Kahramanmaraş/Turkey \\ E-Mail: baysalseda@yahoo.com.tr \\ ORCID: $\underline{0000-0002-3199-1420}$
}

\begin{abstract}
This research attempts to reveal pre-service teachers' perceptions towards instructional technologies (ITs) through colors and emojis along with the meanings attributed to colors and emojis. Synectics model was used to enable students to comment on the concept they are familiar with from a new perspective. The research utilized a phenomenological design. The participants consisted of the $3 \mathrm{rd}$ and 4th grade 161 pre-service teachers learning at a state university between September and December in 2019. Criterion sampling, one of the purposeful sampling methods, was utilized for incorporating only participants who had taken instructional technologies course and who majored in different departments. This research deployed an "instructional technology synectic and emojis form" developed by the researchers. Both content and numerical analysis were used during data analysis. Research findings suggested that the pre-service teachers mostly associated the concept of ITs with white, blue and green colors. The colors that were least preferred were all colors, brown and turquoise. The findings also revealed that most of the participants attributed positive meanings to the colors regarding instructional technologies. Besides, the majority of the pre-service teachers felt "happy" towards instructional technologies and explained the reasons as facilitating learning, feeling special, permanent learning.
\end{abstract}

Keywords: Pre-service teachers, technology, instructional technology, synectics, emoji, colors. 


\section{Öğretmen Adaylarının Öğretim Teknolojilerine İlişkin Algıları ve Görüşleri: Sinektik Modele Dayalı Bir Araştırma}

Öz

$B u$ araştırma, ögrretmen adaylarının öğretim teknolojilerine (BT) yönelik algılarını renkler ve emojilerin yanı sıra renklere ve emojilere atfedilen anlamlarla ortaya çıkarmaya çalışmaktadır. Öğrencilerin aşina oldukları kavrama ilişkin yeni bir perspektif ile yorum yapabilmeleri amacıyla sinektik modeli kullanılmıştır. Araştırmada fenomenolojik bir tasarım kullanılmıştır. Araştırmanın katılımcılarını, 2019 yılı Eylül ve Aralık ayları arasında bir devlet üniversitesinde öğrenim gören 3. ve 4. sinıf 161 öğretmen adayı oluşturmaktadır. Araştırmada amaçlı örnekleme yöntemlerinden olan ölçüt örnekleme kullanılmıştır. Dolayısıyla, araştırmaya yalnızca öğretim teknolojileri dersi almış ve farklı bölümlerde uzmanlaşan katılımcılar dahil edilmiştir. Araştırmada veri toplama aracı olarak, araştırmacılar tarafindan geliştirilen "öğretim teknolojisi sinektik ve emoji formu" kullanılmıştır. Verilerin analizinde, hem içerik analizi hem de sayısal analiz kullanılmıştır. Araştırma bulguları, öğretmen adaylarının BT kavramını çoğunlukla beyaz, mavi ve yeşil renklerle ilişkilendirdiğini ortaya koymuştur. En az tercih edilen renklerin tüm renkler, kahverengi ve turkuaz olduğu sonucuna ulaşılmıştır. Araştırma sonucu, ayrıca katılımcıların çoğunun öğretim teknolojileri ile ilgili renklere olumlu anlamlar yüklediğini ortaya koymuştur. Ayrıca öğretmen adaylarının büyük çoğunluğu öğretim teknolojilerine karşı "mutlu" oldukların ifade etmiş ve bu durumun nedenlerini öğrenmeyi kolaylaştırmak, özel hissetmek, kalıci öğrenme olarak açıklamışlardır.

Anahtar Kelimeler: Öğretmen adayları, teknoloji, öğretim teknolojisi, sinektik, emoji, renkler. 


\section{Introduction}

The desire for using technology to enhance learning and teaching processes has been clear since the early years of the Industrial Revolution, if not earlier. Ever since, numerous initiations have been made in order to use various types of technology for improving teaching and, especially students' learning. However, it was not until the beginning of the $21^{\text {st }}$ century that both technological and human developments provided educational institutions and governments to begin taking advantage of the undoubted capacity of the instructional technologies (ITs) with a view to ensuring teachers to use the tools for improving students' learning in an educational environment (Gedik, 2017; Lee andWinzenried, 2009).

The definitions and scope of ITs have been influenced by numerous psychological, philosophical and scientific orientations (Saettler, 1990). Therefore, no single definition regarding ITs has been universally welcomed (Reiser, 2012). The Association of Educational Communications and Technology (AECT), the most efficient and professional organization for ITs academics and practitioners, has named the terms in different ways such as 'Visual Instruction', 'Audiovisual Instruction', 'Audiovisual Communications', 'Instructional Technology', and 'Educational Technology (ET)' (Lowental and Wilson, 2010). As can be seen from the labels, the first definitions mostly focused on technological tools, while later definitions refer to instruction. AECT defined ITs as "the theory and practice of design, development, utilization, management, and evaluation of processes and resources for learning". Commission on Instructional Technology (1969) described ITs as "a systematic way of designing, carrying out, and evaluating the total process of learning and teaching in terms of specific objectives, based on research in human learning and communication, and employing a combination of human and nonhuman resources to bring about more effective instruction". Based on these definitions, a variety of equipment and teaching materials used for enriching learning activities in accordance with the students' interests, needs and expectations, organizing learning environments in a way that facilitates student learning and supporting learning activities properly can be considered as ITs. Taking into some points, ITs increases the quality of education through facilitating the design and distribution of information 
in different forms, enriching learning activities as well as increasing students' curiosity and motivation (Halis, 2002; Richey and Seels, 1994).

Accordingly, the significance of using ITs in schools is increasing day by day, which necessitates that schools be adequately equipped for ITs. At that point, teachers play a significant role in using teaching technologies effectively in the teaching andlearning process and having wider knowledge, skills and attitudes. Therefore, teachers are required to be equipped with the necessary knowledge and feelings before starting their job (Erdemir, Bakırcı and Eyduran, 2009). Because teachers' attitudes and feelings regarding the learning and teaching process are reflected in the classroom climate (Kuru and Kuru, 2018). Thus, identifying pre-service teachers' perceptions towards ITs are paramount for their professional lives; moreover, using qualitative research methods such as observation, interview or document analysis (DeCarlo andRubba, 1994; Duran andBekdemir, 2013) is considered appropriate as they provide an opportunity to examine individuals' perceptions about a phenomenon or concept in depth and in detail. In addition to analogies and metaphors, synectics that is based on the use of metaphors and analogies can be used in determining the perceptions of individuals and used to obtain creative solutions (Ercan, 2010; Seligmann, 2007). This research used synectics method to identify pre-service teachers' feelings towards the concept of ITs through colors.

The word "synectics" has been originated from Greek roots syn (bring together) and ectics (diverse elements); besides, it fundamentally indicates a structured technique for problem-solving or idea-generation. The term has been defined by some researchers in various ways. First of all, Gordon (1961), the pioneer of the Synectics Model, defined the term as "joining together of different and apparently irrelevant elements". Weaver and Prince (1990) referred to the term as "a creative problem-solving process which carries participants from the analysis of problems to the generation and development of new ideas". Nolan (2003) coined synectics as "a set of process tools derived from video analysis of the methods used successfully in a variety of situations." Estes, Mintz and Gunter (2010) described it as "a structured approach for creating understandings which are not solely novel but unique to the participants", and it is "particularly designed in order to enhance creativity in problem solving through having 
students develop analogies consciously that provide an emotional instead of rational approach to the solutions". As signified by these various definitions, synectics can be regarded as an instructional model which aims to trigger learners' problem-solving and creative thinking skills through making sense of new information via specifically designed techniques.

The basis of synectics lies in the analysis of the invention meetings conducted with a group of individuals who employed numerous metaphors for the purpose of developing new industrial products. The analysis made by Gordon and his team revealed the psychological states of the creative process that promoted divergent and metaphorical thinking (Seligmann, 2007), thus leading to the development of the synectics process in 1955. Then, it became official with the establishment of Synectics, Inc. in Cambridge, Massachusetts in 1960 (Weaver and Prince, 1990). Gordon (1961) pointed out that synectics research is based upon the following hypotheses:

- Individuals' creativity potential can be increased on condition that they understand the psychological process by which they operate

- Emotions and irrationality are much more significant than intellectualism and rationality during creative process

- Emotional and irrational elements can be understood so as to promote the possibility of success in producing creative outcomes.

The Synectics Model, in this regard, is designed in line with the aforementioned hypotheses in order that it could be used as a means in the promotion of creativity and problem-solving capacity. Weaver and Prince (1990) noted that creativity is everyday thinking that requires a connection-making ability for generating new understandings or ideas. This connection-making element is the backbone of the synectics process, which is realized through metaphors. Aristotle clarified that "Metaphor (metaphora) means to attribute a name to the thing that belongs to something else, the transference being either from genus to species, or from species to genus, or from species to species, or on the grounds of analogy." (http://classics.mit.edu/Aristotle/poetics.mb.txt) Metaphor consists of "all figures of speech (e.g. simile, personification, andoxymoron) join together different and irrelevant elements through the use of analogy" (Estes et al., 2010). Hence, the use of metaphors in synectics process enhances students' understanding and learning of new information. There are two 
main versions of Synectics originally used in educational settings including 'Making the Familiar Strange' and 'Making the Strange Familiar' (Gunter, Estes andMintz, 2007; Cited in Asmalı and Dilbaz Sayın, 2016; Gordon, 1991). Figure 1 depicts the stages for each version of synectics.
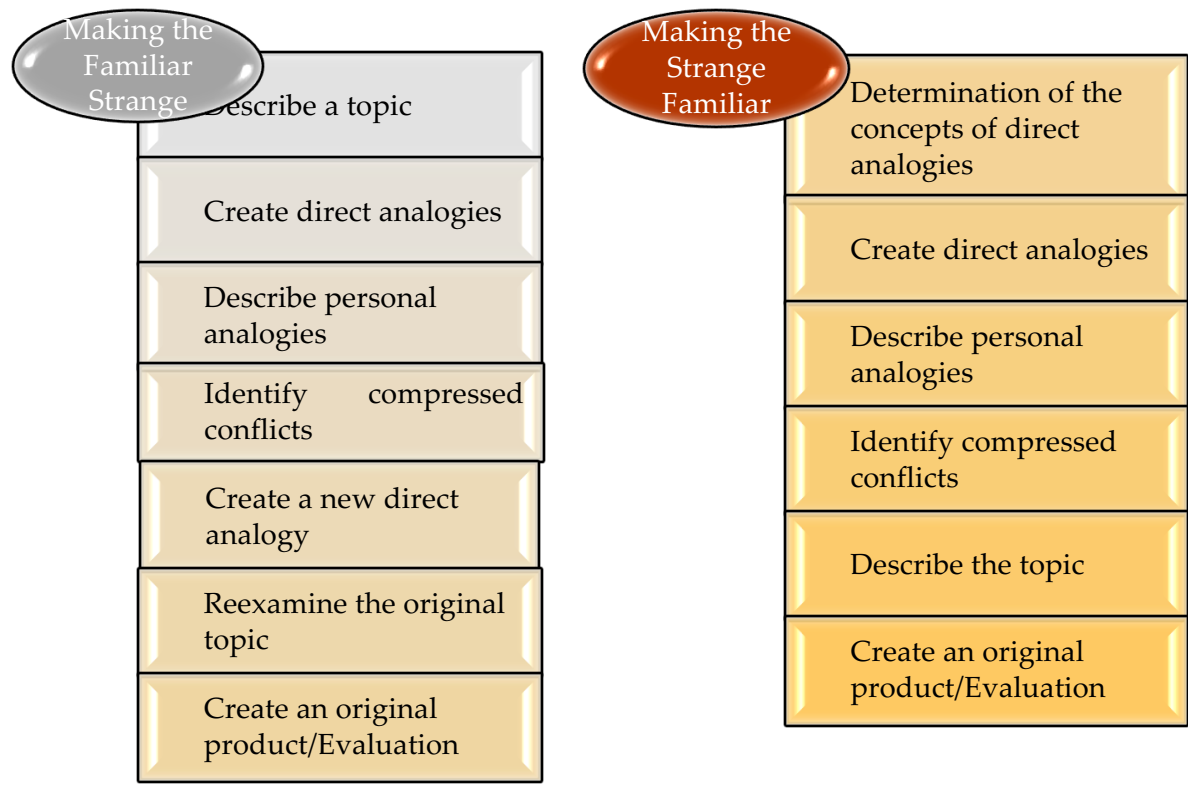

Figure 1. The stages of synectics

The first version 'Making familiar strange' seems like an analytical step as individuals are first supposed to understand the problem. This strangeness is not solely a search for the bizarre and out-of-the-way. It is an attempt made consciously to have a new look at the same old world, people, ideas, feelings, and things. The second version 'Making strange familiar' helps make new knowledge much more meaningful by bridging new and familiar information. When used alone, this version may usually lead only to a variety of superficial solutions. Most problems are not new, yet the challenge is to view the problem in a new way. This new viewpoint in turn hugs the potential for a new basic solution (Prince, 1968). Both versions are vital in the synectics process as they provide individuals an opportunity to involve in creative process. This research employed "Making the 
Familiar Strange (MFS)" as the participants are familiar with the term ITs in advance. Here, a synectic model involving ITs and color concepts were used to enable students to comment on the concept they are familiar with from a new and different perspective.

We live in a world of color (Huchendorf, 2007). Color is defined as the visual perceptual property corresponding in humans to the categories such as red, green, blue, and others. The effect of colors on people has been known since ancient times (Mazlum, 2011). Likewise, Çekinmez (2010) noted that colors have different meanings in people's lives even though all people, except for those who are color blind, see and perceive colors in a similar way. Various researchers have revealed that the color surrounding individuals in their daily lives has a profound impact on their mood, behaviors and their perceptions of the world (Babin, Hardesty, and Suter, 2003; Çalışkan and Kılıç, 2014; Kwallek, Woodson, Lewis, and Sales, 1997). This impact results in the colors having a series of meanings and interpretations to various individuals as well as affecting them emotionally. This paves the way for discussing the close relation between colors and emotions. Color is regarded as one of the most effective factors in a space that affects to express one's emotion (Kurt and Osueke, 2014). Some colors individuals encounter in their daily lives awaken their positive emotions such as happiness, excitement, while others refer to negative emotions such as depression and boredom. This results from the fact that psychological properties of color are associated with moods of people, which means that one's feelings about color may be quiet personal (Çalışkan and Kılıç, 2014). Thus, this research attempts to reveal pre-service teachers' perceptions towards ITs through colors and emojis along with the meanings attributed to these colors and emojis. In this way, the significance of colors in our lives, which is an important component of nonverbal communication, will emerge. Besides, being aware of the psychological and physiological effects of colors may help individuals become much more effective and efficient in the educational process.

Various studies have been conducted on pre-service teachers' perceptions and attitudes towards ITs (Aslan and Zhu, 2015; Adıgüzel, 2010; Bakaç and Özen, 2016; Kuru and Kuru, 2018; Saraç, 2018; Selçuk, 2018; Maharaj-Sharma, Sharma and Sharma, 2017; Willis and Montes, 2002). How- 
ever, there is no such a research specifically published on making an analysis of the pre-service teachers' perceptions towards ITs through use of synectics model and emojis along with their views. In addition, the pattern of the relation between their perceptions and views about ITs is expected to open new gates in terms of guiding researchers and educators in the integration of this new model into their educational practices. This research was conducted with pre-service teachers from different departments. Pre-service teachers take ITs lesson in the fourth term of the school year. They are expected to be familiar with the technology and the use of it in the classes. As a result, this research aimed to analyze the pre-service teachers' perceptions and views on ITs. The research problem was that "What are the pre-service teachers' perceptions and views regarding ITs?". In this regard, Figure 2 depicts the conceptual framework of the research.

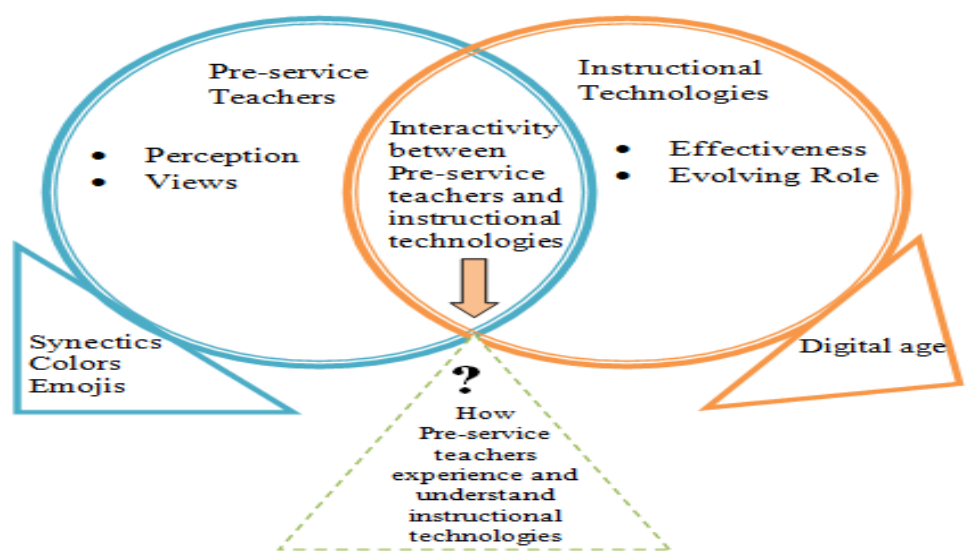

Figure 2. Conceptual framework of the research

Hence, this research attempts to reveal the $3^{\text {rd }}$ and $4^{\text {th }}$ grade pre-service teachers' perceptions and their views regarding ITs. Thus, answers to the following questions were sought:

1. How are the color synectics identified with "ITs" concept by preservice teachers? 
2. What meanings do pre-service teachers ascribe to the colors regarding "ITs" concept?

3. What feelings do the pre-service teachers have about the concept of ITs?

4. What are the pre-service teachers' views on the factors affecting their feelings?

\section{Method}

Research Design: This research utilized a phenomenological design, one of the qualitative research designs. The overall purpose of the phenomenological study is to comprehend and describe a specific phenomenon indepth and get at the essence of participants' lived experience of the phenomenon (Creswell, 2017; Patton, 2002). Phenomenological research is a research design aiming at revealing the perceptions and experiences of the individuals from their own perspectives (Ersoy, 2016). Thus, this research employed a phenomenological design with a view to reaching the essence of the pre-service teachers' lived experience regarding ITs.

Participants: A phenomenological framework requires a relatively homogenous group of participants who are chosen with full of care (Creswell, 2007; Patton, 2002). Therefore, a phenomenological study requires that participants have experience with the same phenomenon. Individuals selected to participate in the phenomenological study are supposed to enjoy significant experiences of the phenomenon being sought (Cresswell, 2007; Moustakas, 1994). A purposeful sampling strategy was first used in order to select the participants with the likelihood they had shaped some experiences around ITs. Then, criterion sampling, one of the purposeful sampling methods, was utilized for incorporating only participants who had taken ITs course and who majored in different departments. In criterion-based selection, researcher(s) had better identify several criteria for all participants for the purpose of selecting participants with the same experiences (Frankael, Wallen and Hyun, 2012). In this regard, the participants of the research held a total of the $3^{\text {rd }}$ and $4^{\text {th }}$ grade 161 pre-service teachers who major in different departments at a state university between 
September and December in 2019. The reason why the $3^{\text {rd }}$ and $4^{\text {th }}$ pre-service teachers were selected was that they had taken ITs course when they were the $2^{\text {nd }}$ graders. Table 1 depicts demographic information regarding the participants.

Table 1. Demographic Information Regarding the Participants

\begin{tabular}{llll}
\hline Variables & & $\mathrm{N}$ & $\%$ \\
\hline Gender & Female & 125 & 77,63 \\
& Male & 36 & 22,36 \\
\hline Department & Classroom Teaching & 69 & 42,85 \\
& Science Teaching & 24 & 14,90 \\
& Turkish Language Teaching & 48 & 29,81 \\
& Social Sciences Teaching & 20 & 12,42 \\
\hline Class Level & 3rd grade & 112 & 69,56 \\
& 4th grade & 49 & 30,43 \\
\hline Total & & 161 & 100,00 \\
\hline
\end{tabular}

Table 1 portrays that $125(56.0 \%)$ of the pre-service teachers are female and $36(44.0 \%)$ are male. Considering the departments, the pre-service teachers mostly study classroom teaching $(f=69,32.2 \%)$, and the fewest is the social sciences teaching $(\mathrm{f}=20,19.8 \%)$, while they were mostly $3^{\text {rd }}$ graders $(\mathrm{f}=112,67.8 \%)$, and the rest of them were the $4^{\text {th }}$ graders $(\mathrm{f}=49,32.2 \%)$.

Data Collection Tool: This research deployed "Instructional technologies synectic and emojis form" developed by the researchers through asking expert opinions for the purpose of providing the construct and content validity. The form got their final version after evaluating feedback presented by two experts from Curriculum and Instruction Department. The form includes two parts. The synectic part of the form was developed to identify the pre-service teachers' perceptions towards ITs through colors. In the first stage, the statement "Instructional Technologies resemble to ....... color" was used to determine which colors pre-service teachers use to refer to the concept of ITs. In the second stage, the statement "because .." was written in order to explain the underlying reasons why they prefer the color. In such studies, the statement "resemble" is used to determine the mental image or perception, and "because" to provide a logical basis (Saban, 2009).

The "emojis" part of the form was prepared for revealing the pre-service teachers' emotions regarding ITs and the underlying reasons for the 
selection of emojis. The emojis used in the form were determined by taking into consideration the most commonly used symbols in recent years in communication. The meanings of the emojis were noted under each. These meanings were quoted from a website. Figure 3 presents the emojis and their meanings.

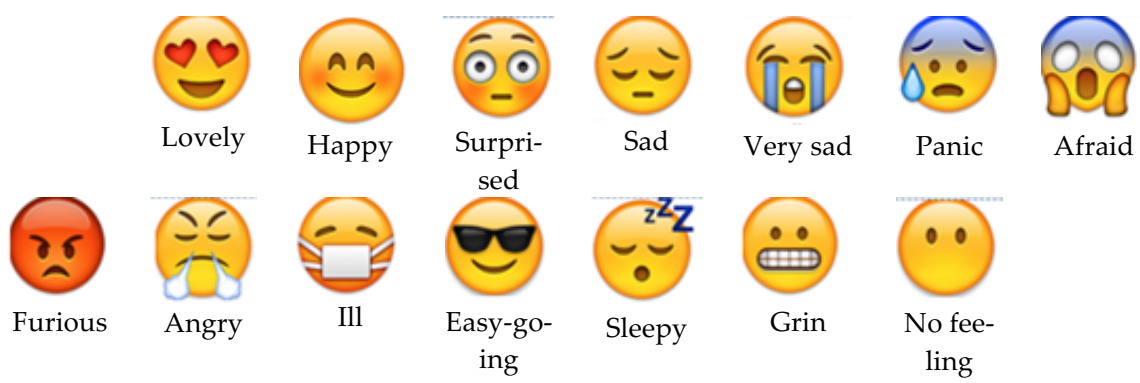

Figure 3. Emojis and their meanings

Data Collection Process: The research data were collected within three weeks in the participants' classrooms. While administering the form, the participants were informed about the purpose of the research. The participants filled the form in approximately 5-10 minutes.

Validity and Reliability of the Research: Creswell (2009) and Lincoln and Guba (1985) asserted that "validity" is related to the accuracy of scientific findings and "reliability" is the repeatability of scientific findings in qualitative research. In this context, the following steps were conducted to increase the validity and reliability of the research.

a) A conceptual framework was developed with the help of the literature review during the development process of the synectic and emojis form with a view to increasing the internal validity of the research. In order to ensure credibility, the research must be presented to the experts who can legitimately judge the credibility of the results. Therefore, this research was presented to two education faculty instructors working at state universities in Turkey and having qualitative research experience. Besides, the correlation between the categories and codes constituting the themes and the relationship of each category with the others were ensured in the 
content analysis. Besides, the participant confirmation was provided after the findings and comments were approved through the data sources. That the names would be coded during reporting process is of great importance in ensuring mutual trust. Thus, the elicited data were to reflect the real situation.

b) The research must include descriptions, namely, direct quotes from participants in order to ensure transferability (Yildırım and Şimşek, 2005). In this research, extracts were presented for each category, and they were incorporated into the findings section. The research process was explained in detail to increase the external validity (transferability) of the research. Thus, an in-depth presentation of the research design, working group, data collection tool, data collection process and data analysis was performed. The forms were collected from the voluntary participants and a purposive sampling method was utilized in order to reveal the varying characteristics of the phenomenon. The research findings were interpreted and discussed in such a way to provide contribution to the curriculum and instruction literature.

c) With a view to increasing the dependability of the research, all of the obtained findings were presented directly to the reader without any comment and generalization.

d) The data collection tool, raw data and codifications were presented to the experts' views for increasing the external reliability (confirmability) of the research.

Data Analysis: This research utilized both content and numerical analysis during data analysis. Numerical analysis is a type of analysis which is used in qualitative research and in which frequency and percentage values are presented (Ylldırım and Şimşek, 2005). Therefore, numerical analysis was used in the current research as the data was presented to the readers by specifying frequency and percentage values. The research also welcomed content analysis for in-depth data analysis. Content analysis is defined as an analytical method that attempts to identify and derive meanings from a wide range of text-based data (Creswell, 2007; Krippendorff, 2004). The content analysis of the elicited data was carried out by taking into consideration the steps such as coding the data, creating categories, 
arranging the codes and categories, defining and interpreting the findings. After the analysis was completed, the research data was presented to an expert and the data was re-analyzed. In line with the analyzes made by the researchers and the expert, the codes and the categories were re-examined and the necessary corrections were made with full of consent. In this regard, the categories of "ITs as a symbol of production and discovery" and "ITs as a symbol of innovation and creativity" were combined. Thus, a new category was formed as "ITs as a symbol of innovation, discovery, creativity and production". Finally, a total of 16 different categories were identified and different meanings were ascribed to the same colors such as white, blue, yellow etc., and they were placed under more than one category. Last but not least, direct quotes were presented in order to unveil the underlying meanings of the codes. To ensure the confidentiality of the pre-service teachers, they were coded with numbers and letters (PT:1, PT $=$ Pre-service Teacher 1 ).

\section{Findings}

Findings regarding the color synectics identified with "ITs" concept by the pre-service teachers

As a result of the analyzes carried out within the scope of the research, color codes produced by the pre-service teachers for ITs were identified and frequency and percentage values for these codes were calculated. Table 2 depicts the colors and the frequency and percentage values that the pre-service teachers associated with the concept of ITs.

Table 2 displays that the pre-service teachers identified 12 different color codes related to the concept of ITs. Accordingly, pre-service teachers were determined to mostly associate the concept of ITs with white, blue and green colors. Considering their frequency values, these colors were followed by yellow, red, grey, black, purple and orange. The colors that were least preferred by the pre-service teachers were all colors, brown and turquoise. 
Table 2. The findings regarding the color synectics identified for "ITs" concept by the pre-service teachers

\begin{tabular}{lll}
\hline Codes & f & \% \\
\hline White & 47 & 29,19 \\
Blue & 29 & 18,01 \\
Green & 23 & 14,28 \\
Yellow & 21 & 13,04 \\
Red & 21 & 13,04 \\
Grey & 6 & 3,72 \\
Black & 5 & 3,10 \\
Purple & 4 & 2,48 \\
Orange & 2 & 1,24 \\
All colors & 1 & 0,62 \\
Brown & 1 & 0,62 \\
Turquoise & 1 & 0,62 \\
\hline Total & $\mathbf{1 6 1}$ & $\mathbf{1 0 0}$ \\
\hline
\end{tabular}

Findings regarding the meanings ascribed to the colors by pre-service teachers related to "ITs" concept

As a result of the research analyzes, the meanings that pre-service teachers ascribed to the colors with regard to the concept of ITs were classified as those having positive, negative, both positive and negative meanings and the results are presented in Table 3.

Table 3.The findings regarding the meanings ascribed to the color synectics by the preservice teachers

\begin{tabular}{|c|c|c|c|c|c|c|c|c|c|}
\hline \multirow{11}{*}{$\begin{array}{l}\text { Color } \\
\text { codes }\end{array}$} & Positive & $\mathrm{f}$ & $\%$ & Negative & $\mathrm{f}$ & $\%$ & $\begin{array}{l}\text { Both positive } \\
\text { and negative }\end{array}$ & $\mathrm{f}$ & $\%$ \\
\hline & White & 46 & 28,57 & Gray & 5 & 3,10 & Red & 3 & 1,86 \\
\hline & Blue & 29 & 18,01 & Black & 3 & 1,86 & Yellow & 1 & 0,62 \\
\hline & Green & 23 & 14,28 & White & 1 & 0,62 & Gray & 1 & 0,62 \\
\hline & Yellow & 20 & 12,42 & & & & Black & 1 & 0,62 \\
\hline & Red & 18 & 11,18 & & & & Brown & 1 & 0,62 \\
\hline & Purple & 4 & 2,48 & & & & & & \\
\hline & Orange & 2 & 1,24 & & & & & & \\
\hline & Black & 1 & 0,62 & & & & & & \\
\hline & All colors & 1 & 0,62 & & & & & & \\
\hline & Turquoise & 1 & 0,62 & & & & & & \\
\hline Total & & 145 & & & 9 & & & 7 & \\
\hline
\end{tabular}

As can be seen from Table 3, most of the pre-service teachers attributed positive meanings to colors regarding the concept of ITs. Upon analyzing the pre-service teachers' color preferences, they were identified to have 
Pre-service Teachers' Perceptions and Views towards Instructional Technologies: A Study Based upon Synectic Model

the most positive meaning for the white color and the least for turquoise. Table 3 also suggests that the pre-service teachers attributed negative meanings to gray, black and white colors. Besides, the pre-service teachers were determined to attribute both negative and positive meanings to the red, yellow, gray, black and brown.

The elicited color codes were categorized depending on the meanings attributed to colors by the pre-service teachers; besides, the frequency and percentage values of these categories were calculated. In line with the preservice teachers' perceptions regarding ITs, 16 conceptual categories were identified. The categories and the associated colors determined through examining the rationale of the color codes regarding the concept of ITs are presented in Table 4.

Table 4.The findings regarding the conceptual categories and colors of ITs

\begin{tabular}{|c|c|c|c|}
\hline Conceptual Categories & Codes & f & $\%$ \\
\hline $\begin{array}{l}\text { 1.ITs as a symbol of wholeness } \\
\text { and wide area }\end{array}$ & $\begin{array}{l}\text { White (25), Blue (6), Green (1) } \\
\text { Purple (1), All colors (1) }\end{array}$ & 34 & 20,48 \\
\hline \multicolumn{2}{|c|}{$\begin{array}{l}\text { 2.ITs as a symbol of innovation, discovery, crea-Green (15), White (4), } \\
\text { tivity and production } \\
\text { Blue (4), Yellow (2), Turquoise (1) }\end{array}$} & 26 & 15,66 \\
\hline 3.ITs as a symbol of vitality and dynamism & $\begin{array}{l}\text { Red (12), Yellow (7), } \\
\text { Blue (1), Purple (1) }\end{array}$ & 21 & 15,65 \\
\hline 4.ITs as a symbol of enlightenment & $\begin{array}{l}\text { Yellow (7), White (6), } \\
\text { Green (2), Purple (1) }\end{array}$ & 16 & 9,63 \\
\hline $\begin{array}{l}\text { 5.ITs as a symbol of teaching } \\
\text { and effectiveness }\end{array}$ & Red (6), White (3), Purple (1) & 10 & 6,02 \\
\hline $\begin{array}{l}\text { 6.ITs as a symbol of complex } \\
\text { emotions }\end{array}$ & $\begin{array}{l}\text { Grey (3), Red (2), Yellow (1), } \\
\text { Black (1), Brown (1) }\end{array}$ & 8 & 4,81 \\
\hline 7.ITs as a symbol of progress & $\begin{array}{l}\text { Blue (3), White (1), } \\
\text { Green (1), Yellow (1), Orange (1) }\end{array}$ & 7 & 4,21 \\
\hline 8.ITs as a symbol of daily life & $\begin{array}{l}\text { White (3), Green (1), } \\
\text { Yellow (1), Blue (1), Red (1) }\end{array}$ & 7 & 4,21 \\
\hline 9.ITs as a symbol of tranquility & Blue (7) & 7 & 4,21 \\
\hline 10.ITs as a symbol of eternity & Blue (5), White (1) & 6 & 3,61 \\
\hline 11.ITs as a symbol of pessimism & Grey (2), Black (2), White (1) & 5 & 3,01 \\
\hline 12.ITs as a symbol of trust & Blue (4), White (1) & 5 & 3,01 \\
\hline 13.ITs as a symbol of mystery & Black (2), Grey (1), White (1) & 4 & 2,40 \\
\hline $\begin{array}{l}\text { 14.ITs as a symbol of neutrality } \\
\text { and transparency }\end{array}$ & White (3), Orange (1) & 4 & 2,40 \\
\hline $\begin{array}{l}\text { 15.ITs as a symbol of harmony } \\
\text { and balance }\end{array}$ & Green (2), Yellow (2) & 4 & 2,40 \\
\hline 16.ITs as a symbol of authenticity & White (1), Green (1) & 2 & 1,20 \\
\hline Total & & 166 & 100 \\
\hline
\end{tabular}


Upon analyzing Table 4, pre-service teachers were identified to mostly mention the category of "ITs as a symbol of wholeness and wide area" $(\mathrm{f}=34)$, while the least mentioned one was "ITs as a symbol of authenticity" $(\mathrm{f}=2)$. Table 4 also suggests that different meanings were ascribed to the same colors such as white, blue, yellow etc., and they were placed under more than one category. To illustrate, the blue color was categorized under "ITs as a symbol of wholeness and wide area" $(\mathrm{f}=6)$, "ITs as a symbol of innovation, discovery, creativity and production" ( $\mathrm{f}=4$ ), "ITs as a symbol of vitality and dynamism" ( $\mathrm{f}=1)$. Descriptions and pre-service teachers' statements related to the categories are displayed below.

ITs as a symbol of wholeness and wide area: The category of "ITs as a symbol of wholeness and wide" was formed since the pre-service teachers noted that "ITs" is a combination of knowledge from different disciplines and indicate that the content has a wide area. This category includes the colors such as white $(\mathrm{f}=25)$, blue $(\mathrm{f}=6)$, green $(\mathrm{f}=1)$, purple $(\mathrm{f}=1)$, all colors $(\mathrm{f}=1)$. Some of the pre-service teachers explained the relationship between the selected color and ITs with the following words.

"ITs .....resemble to white color... because it covers all colors. ITs also include all kinds of information. When teaching something, it is essential to use most of ITs, meaning that it is very comprehensive." (PT40)

"ITs .... resemble to white color... because it includes all colors. ITs also include all the objectives and learning. Therefore, it has a very wide area" (PT15)

"ITs .... resemble to blue color... because the sky is blue and quite wide. That is, ITs are very extensive. ITs encourage students to look at the events from a broader perspective" (PT154)

"ITs ..... resemble to all colors... because they are required in all lessons such as English, Maths, Social Sciences etc. during the educational process" (PT26)

ITs as a symbol of innovation, discovery, creativity and production: Upon examining the colors in this category, it is wise to mention that the common feature of the colors was associated with innovation, discovery, creativity and production. It is regarded as the second mostly mentioned category by the pre-service teachers $(\mathrm{f}=26)$. The category includes the colors such as green $(\mathrm{f}=15)$, white $(\mathrm{f}=4)$, blue $(\mathrm{f}=4)$, yellow $(\mathrm{f}=2)$, turquoise 
$(\mathrm{f}=1)$. Some of the participants explain the reasons in the following extracts.

"ITs ..... resemble to green color.... because the green color expresses creative thinking according to the 6-hat thinking technique. ITs, just as the green color, help the individual expand their horizons and think creatively." (PT107)

"ITs ..... resemble to green color... because green is a creative and innovative color. It also refers to productivity. ITs are always open to innovation and production." (PT125)

"They resemble to yellow color.... because ... for me, it evokes creativity and refers to brightness and new ideas, that is, creativity." (PT162)

"The turquoise color reminds me of creativeness and difference. Therefore, I associate it with ITs." (PT59)

"The color blue is associated with the imagination. The larger your imagination and creativity, the more likely it is to succeed in IT." (PT47)

ITs as a symbol of vitality and dynamism: When the color codes in this category were examined, the common feature was determined to be associated with vitality and dynamism. The reason for the emergence of this category was that the pre-service teachers associated ITs with red $(\mathrm{f}=12)$, yellow $(\mathrm{f}=7)$, blue $(\mathrm{f}=1)$, purple $(\mathrm{f}=1)$ colors as these colors indicated the constant change and improvement as well as the vitality. The related preservice teachers' views are exemplified in the following quotes.

"ITs ..... resemble to blue color... because this color indicates constant change, so ITs always need update." (PT21)

"ITs ..... resemble to purple color... because ITs require performance with full of energy and purple reminds me of vitality" (PT39)

"ITs ..... resemble to red color... because red color is at the front in terms of drawing attention. It is alive, and it has a dynamic within itself." (PT159)

"I associate ITs with yellow color because this color reminds me of sun and it is shining and vital. ITs keep the students alive." (PT114)

ITs as a symbol of enlightenment: This category was formed as a result of the pre-service teachers' expressions that "ITs" bear the role of enlightening people. Accordingly, the pre-service teachers were found to associate "ITs" with such colors as yellow $(\mathrm{f}=7)$, white $(\mathrm{f}=6)$, green $(\mathrm{f}=2)$, purple $(\mathrm{f}=1)$. 
The definitions of the color codes by the pre-service teachers are presented in the following examples.

"ITs ..... resemble to white color.... because it sheds light on the teacher about how to use the objectives. It enlightens the teacher as well as the students." (PT158)

"ITs ..... resemble to purple color... because this color is very bright and it enlightens the world. ITs also enlighten people's lives" (PT8)

"I associate ITs with the green color because it enlightens us and each learning area is our horizon line." (PT65)

"ITs ..... resemble to yellow color... because they brighten the surroundings like a yellow color and allow us to see and understand the information remaining in the invisible background. Just as the sun rising every day illuminates our environment with its yellow color, ITs enlighten us." (PT139)

ITs as a symbol of teaching and effectiveness: When the color codes in this category were examined, the common feature was found to be teaching and effectiveness. What was meant here was the significance of the concept of IT in terms of teaching and its effectiveness. Considering that the concept of IT is worth in teaching process, colors red $(\mathrm{f}=6)$, white $(\mathrm{f}=3)$, purple ( $\mathrm{f}=1$ ) were produced by the pre-service teachers. The following extracts were drawn from the pre-service teachers' statements.

"ITs .... resemble to white color... because ITs are both useful and important for the students. It can be used in many different areas for effective teaching. They are important teaching tools for students to gain skills." (PT108)

"ITs .... resemble to red color... because red is an important and effective color. Also, it is remarkable. ITs are also paramount in the teaching process and it is important to use them effectively. Their use in the classroom is also important in terms of attracting students' attention." (PT7)

"ITs .... resemble to red color... because it is a remarkable color and therefore, the use of ITs in the classes attract attention." (PT87)

ITs as a symbol of complex emotions: The research findings revealed that some of the pre-service teachers stated both positive and negative aspects of ITs while associating them with colors, Accordingly, the ITs category was identified as a symbol of complex emotions including the colors such as grey $(\mathrm{f}=3)$, red $(\mathrm{f}=2)$, yellow $(\mathrm{f}=1)$, black $(\mathrm{f}=1)$, brown $(\mathrm{f}=1)$. In this regard, 
the definitions of the color codes by the pre-service teachers are depicted in the following examples.

"ITs ..... resemble to grey color... because this color is complex and intense so ITs are also very complex and intense" (PT50)

"ITs ..... resemble to red color... because it gets balanced when you get away, but it burns when you get close." (PT55)

"ITs ..... resemble to black color... because at times it becomes a savior and at times it can ruin everything." (PT145)

"ITs ..... resemble to brown color... because this is perfect when used well and bad when used poorly. This is the case in ITs." (PT92)

ITs as a symbol of progress: This category was formed as a result of the pre-service teachers expressions that "ITs" pave way for the development. Thus, the pre-service teachers were determined to associate "ITs" with such colors as blue $(\mathrm{f}=3)$, white $(\mathrm{f}=1)$, green $(\mathrm{f}=1)$, yellow $(\mathrm{f}=1)$, orange $(\mathrm{f}=1)$. The definitions of the color codes by the pre-service teachers are given in the following examples.

"ITs ..... resemble to green color.... because they are constantly renewing and developing like nature." (PT20)

"ITs .... resemble to green color... because I believe that the yellow color indicates development as it shines. In this developing technology world, ITs are also constantly developing and progressing." (PT113)

"ITs ..... resemble to orange color... because IT are constantly changing and evolving, and they emit orange-like color. It is reminiscent of orange as IT are free and progressing." (PT33)

"ITs ..... resemble to blue color... because this color refers to have new horizons. Therefore, ITs have a style of being open to the developments." (PT126)

ITs as a symbol of daily life: Table 4 suggested that pre-service teachers associated ITs with daily life and mentioned the necessity of ITs for life. Hence, this category was created as a symbol of daily life with the colors such as white $(\mathrm{f}=3)$, green $(\mathrm{f}=1)$, yellow $(\mathrm{f}=1)$, blue $(\mathrm{f}=1)$, red $(\mathrm{f}=1)$. The preservice teachers' views on this category are exemplified in the following quotes. 
"ITs ..... resemble to green color... because green is a color of assets. Green is very important in life. The importance of ITs in education is undeniable since it helps our daily lives." (PT109)

"ITs ..... resemble to white color... because this color is transparent. ITs course should also reflect transparency and daily life." (PT156)

"ITs ..... resemble to yellow color.... because yellow is reminiscent of the sun and is important to sustain our lives. ITs are also essential in our daily lives like sun." (PT2)

ITs as a symbol of tranquility: The research findings showed that some of the pre-service teachers mentioned the significance of ITs for peace while associating them with colors. Therefore, the ITs category was identified as a symbol of tranquility including the color blue $(\mathrm{f}=7)$. In this context, the definitions of the color codes by the pre-service teachers are depicted in the following examples.

"ITs ..... resemble to white color... because blue is the color of the sky. The sky gives you peace. The people looking at the sky get away from their troubles. ITs also provide students with different ways of comforting them and enabling them to learn better." (PT29)

"ITs ..... resemble to white color.... because just as the blue color gives people peace and guidance, we relax and apply the right things when we apply ITs." (PT75)

"ITs ..... resemble to white color... because blue is a calming color, ITs also calm students and facilitate education." (PT62)

ITs as a symbol of eternity: When the color codes in this category were examined, the common feature was determined to be associated with eternity. The pre-service teachers associated ITs with blue $(\mathrm{f}=5)$ and white $(\mathrm{f}=1)$ colors as these colors the eternity of our imagination. The definitions of the color codes by the pre-service teachers are displayed in the following examples.

"ITs ..... resemble to blue color.... because they are infinite like blue. It is the point where our imagination reaches infinity..." (PT93)

"ITs .... resemble to blue color... because it is a color that expresses eternity. ITs will also continue to evolve and develop. They reflect infinity."(PT77) 
"ITs .... resemble to blue color... because IT have a wide area like the sky, and there is the possibility of infinite thinking in ITs." (PT68)

ITs as a symbol of pessimism: Table 4 illustrated that pre-service teachers associated ITs with pessimism and expressed their anxiety and hopelessness about ITs. Hence, this category was created as a symbol of pessimism with the colors such as grey $(\mathrm{f}=2)$, black $(\mathrm{f}=2)$, white $(\mathrm{f}=1)$. In this regard, the pre-service teachers' views on this category are exemplified in the following statements.

"ITs ..... resemble to black color... because I have failed in this lesson am still trying to pass it. I am nervous." (PT49)

"ITs ..... resemble to grey color... because I think I cannot make the grey color meaningful just as ITs. We do not fully understand the limits and necessity of using technology in education and learning process. When we want to use one of these technologies, we immediately start doing something but it fails." (PT124)

"ITs .... resemble to white color... because it doesn't mean anything to me like white, and it won't. I do not have any knowledge and skills about it." (PT132)

ITs as a symbol of trust: This category was formed as a result of the preservice teachers expressions that "ITs" provide trust. Thus, the pre-service teachers were identified to associate "ITs" with such colors as blue $(\mathrm{f}=4)$ and white $(\mathrm{f}=1)$. The definitions of the color codes by the pre-service teachers are given in the following statements.

"ITs ..... resemble to blue color... because this color is intimate and ensures confidence. Technology and teaching draws the attention of the students and enables them to approach the lessons with sincerity. At the same time, teaching via technology gives more confidence than using traditional teaching methods." (PT101)

"ITs ..... resemble to white color... because it makes you feel safe. When facing with a variety of IT, students need confidence that they can learn subjects better."(PT76)

ITs as a symbol of mystery: Table 4 suggested that the pre-service teachers associated ITs with mystery and they resembled them to night, secret. Hence, this category was created as a symbol of mystery with the colors 
of black ( $\mathrm{f}=2)$, grey $(\mathrm{f}=1)$, white $(\mathrm{f}=1)$. Thus, the pre-service teachers' views on this category are given in the following expressions.

"ITs ..... resemble to black color... because this color hides everything, it has lots behind. It's like night. Nothing seems to exist, but there are too many things. ITs are like black, like an agent." (PT52)

"ITs .... resemble to black color... because it contains all colors but it is mysterious. Instructional technologies also include many things. It seems that there are very few features, but this is not the case." (PT129)

ITs as a symbol of neutrality and transparency: This category was formed by taking into account the pre-service teachers expressions that "ITs" are neutral and transparent. Thus, the pre-service teachers were found to associate "ITs" with such colors as white $(\mathrm{f}=3)$ and orange $(\mathrm{f}=1)$. The preservice teachers' views on this category are exemplified in the following quotes.

"ITs ..... resemble to orange color... because this color has no gender. I think this course can appeal to everyone." (PT71)

"ITs ..... resemble to white color... because this color represents transparency and objectivity. No matter what technologies are used, the information is transparent as it is reliable." (PT117)

"ITs ..... resemble to white color... because ITs are neutral. For whatever purpose they are used, they serve that purpose." (PT22)

ITs as a symbol of harmony and balance: Upon examining the colors in this category, it is logical to mention that the common feature of the colors was associated with harmony and balance. The category includes the colors such as green $(\mathrm{f}=2)$, and yellow $(\mathrm{f}=2)$. Some of the participants explain the reasons in the following extracts.

"ITs .... resemble to green color... because this color signifies harmony and balance. ITs are also in harmony and balance with the students during the education process."(PT98)

"ITs ..... resemble to yellow color.... because the yellow color is a harmonious color, everything suits. ITs are also compatible for all courses." (PT91)

ITs as a symbol of authenticity: When the color codes in this category were examined, the common feature was found to be originality. Given 
that the concept of ITs is authentic in teaching process, colors white $(\mathrm{f}=1)$ and green $(\mathrm{f}=1)$ were produced by the pre-service teachers. The following extracts were drawn from the pre-service teachers' statements.

"ITs ..... resemble to green color... because ITs are as unique as green. Green is unique in nature and ITs are unique in classrooms" (PT5)

"ITs ..... resemble to white color... because it is a unique color that contains all colors. So are ITs." (PT16)

\section{Findings regarding the feelings the pre-service teachers have about the concept of ITs}

The research findings revealed the pre-service teachers' feelings about the ITs and the reasons for these feelings. Table 5 presents the findings related to the feelings pre-service teachers have towards ITs.

Table 5. Findings related to the frequency and percentage values of the emojis expressing the emotions that pre-service teachers have towards Its

\begin{tabular}{|c|c|c|c|c|c|}
\hline Emojis & $\mathrm{f}$ & $\%$ & Emojis & $\mathbf{f}$ & $\%$ \\
\hline ( & 70 & 43,47 & $\therefore$ & 3 & 1,86 \\
\hline$(28$ & 33 & 20,49 & (T) & 2 & 1,24 \\
\hline$\theta$ & 27 & 16,77 & -0 & 2 & 1,24 \\
\hline$\because$ & 8 & 4,96 & $\because$ & 1 & 0,62 \\
\hline$\because$ & 5 & 3,10 & $=6$ & - & - \\
\hline 600 & 4 & 2,48 & (2) & - & - \\
\hline ๑๐- & 3 & 1,86 & $\because \because$ & - & - \\
\hline$=$ & 3 & 1,86 & & & \\
\hline
\end{tabular}

Table 5 suggests that the majority of the pre-service teachers felt "happy" towards ITs, which were followed by lovely ( $\mathrm{f}=33$ ), easy-going $(\mathrm{f}=27)$ and calm $(\mathrm{f}=8)$. A small number of pre-service teachers were identified to prefer the emojis such as afraid $(\mathrm{f}=4)$, surprised $(\mathrm{f}=3)$, $\operatorname{sad}(\mathrm{f}=3)$, grin $(\mathrm{f}=3)$, very sad $(\mathrm{f}=2)$, ill $(\mathrm{f}=2)$ and sleepy $(\mathrm{f}=1)$. Besides, pre-service teachers did not prefer the emojis such as angry, furious and panic. 
Findings regarding the pre-service teachers' views on the factors affecting their feelings with regard to the concept of ITs

The research findings unveiled the pre-service teachers' views on the factors affecting their feelings with regard to the concept of ITs. Table 6 presents the findings related to the factors affecting pre-service teachers' feelings.

Table 6. Findings related to the frequency and percentage values of the factors affecting the pre-service teachers' feelings with regard to the concept of ITs

\begin{tabular}{|c|c|c|c|}
\hline Category & Code & $\mathbf{f}$ & $\%$ \\
\hline \multirow{8}{*}{ Positive } & Facilitate learning and teaching process & 38 & 23,60 \\
\hline & Attractive & 36 & 22,36 \\
\hline & Facilitate daily life & 22 & 13,66 \\
\hline & Feel special & 21 & 13,04 \\
\hline & Permanent learning & 11 & 6,83 \\
\hline & Provide Creativeness & 8 & 4,96 \\
\hline & Ensure interaction & 2 & 1,24 \\
\hline & Total & 138 & 85,71 \\
\hline \multirow{7}{*}{ Negative } & Feel insufficient & 4 & 2,48 \\
\hline & Adverse effects on health & 3 & 1,86 \\
\hline & Dislike using technology in the class & 2 & 1,24 \\
\hline & Instructors' effect & 1 & 0,62 \\
\hline & Fail in the exam & 1 & 0,62 \\
\hline & Unable to follow current technology & 1 & 0,62 \\
\hline & Total & 12 & 7,45 \\
\hline \multirow{5}{*}{ Hesitant } & Lack of knowledge & 6 & 3,72 \\
\hline & No idea about to what extent they are used & 2 & 1,24 \\
\hline & Both beneficial and harmful & 2 & 1,24 \\
\hline & Depending on teacher & 1 & 0,62 \\
\hline & Total & 11 & 6,84 \\
\hline
\end{tabular}

Table 6 displays the frequency and percentage values of the factors affecting the pre-service teachers' feelings with regard to the concept of ITs. Accordingly, three categories including positive feelings, negative feelings and hesitant and seventeen codes were obtained. As can be seen in Table 6, pre-service teachers were identified to mostly feel positive towards the concept of ITs, and the mostly outstanding code in the positive category was found as facilitating learning and teaching process ( $\mathrm{f}=38)$, while the least mentioned code was ensure interaction $(\mathrm{f}=2)$. When it comes to the negative category, the pre-service teachers were determined to mostly feel insufficient ( $\mathrm{f}=4$ ) in terms of ITs, which were followed by adverse effects on health $(\mathrm{f}=3)$, dislike using technology in the class $(\mathrm{f}=2)$, instructors' effect $(\mathrm{f}=1)$, 
fail in the exam $(\mathrm{f}=1)$, unable to follow current technology $(\mathrm{f}=1)$. Table 6 also suggests that pre-service teachers were hesitant towards ITs including the codes such as lack of knowledge $(\mathrm{f}=6)$, no idea about to what extent they are used $(\mathrm{f}=2)$, both beneficial and harmful $(\mathrm{f}=2)$ and depending on teacher $(\mathrm{f}=1)$. Some of the participants explain the reasons in the following extracts.

Because I love these technologies and they make my life easier. (PT144)

Because it means creativity and permanent learning for me. When I hear this concept, my eyes shine and I feel happy. I feel lucky for taking this lesson. (PT162)

It looks so cool. ITs make one feel special. (PT37)

Because learning with ITs becomes more permanent and efficient. (PT110)

Being familiar with ITs smakes our daily life easier. It enables us to solve problems in daily life more easily by developing skills such as creative thinking and analytical thinking. (PT159)

Because using ITs in the classroom increases communication and interaction between students. (PT67)

I'm obviously hesitant about it. Because it has both advantages and disadvantages. (PT65)

During the lesson, the students arouse curiosity and enable the course to be more interesting. (PT95)

I feel cool and different. Because using ITs makes a difference. (PT40)

I don't like to use it because my eyes hurt. (PT150)

I can't think of anything positive because I failed in this lesson. (PT49)

I think it should actually be used and it is useful. But I have insufficient knowledge on this. (PT130)

\section{Discussion and Result}

This research was conducted to reveal the $3^{\text {rd }}$ and $4^{\text {th }}$ grade pre-service teachers' perceptions through color synectics and colors as well as their views regarding ITs. In the first phase of the research, the pre-service teachers were asked to associate colors with the concept of ITs as colors have been identified to increase a person's arousal. Colors may directly affect individuals' emotions, thoughts and actions (Mazlum, 2011). Besides, they have a subterranean result on how people feel both psychologically and physically (Huchendorf, 2007; Mazlum, 2011). Research findings revealed that the pre-service teachers associated the concept of ITs 
with different colors. In addition, they were found to attribute different meanings to the same color. Valdez and Mehrabian (1994), Küçük (2010) and Epps and Kaya (2004) stated that colors may hold different meanings in terms of cultural and sociological aspects and that the same color can be used in different meanings. To illustrate, white is the color of mourning and symbolizes death in Eastern cultures. In Japan, especially white carnations are associated with death. On the other hand, it is used for wedding dresses as the color of purity in western cultures (Ambrose and Haris, 2003).

Research findings also suggested that the pre-service teachers mostly associated the concept of ITs with white, blue and green colors. Considering their frequency values, these colors were followed by yellow, red, grey, black, purple and orange. The colors that were least preferred by the pre-service teachers were all colors, brown and turquoise. The pre-service teachers mostly preferred white color as they thought that it covers all colors and IT also include all kinds of information. In his study, Polat (2012) noted that the white color is the mixture of green, red and blue, meaning that it has a wide area.

As a result of the analysis, most of the pre-service teachers were identified to attribute positive meanings to the colors regarding the concept of ITs. This may be due to the positive effects of the previous experiences they had while receiving the course. Similar results emerged in the studies conducted by Selçuk (2018) and Saraç (2018). Upon analyzing the pre-service teachers' color preferences, they were identified to attribute the most positive meaning to the white color. This may result from the fact that white color evokes purity and it has a peaceful, neutral and calm tone (Mazlum, 2011; Uçar, 2004), meaning that white color may create positive perception. In another study carried out by Saito (1996), white was identified to be positively associated with the feelings such as being clean, pure, clear, and peaceful. Besides, in the studies conducted by Çalışkan and Kılıç (2014) and Huchendorf (2007), white color was found to generally associate with positive meanings. These findings are consistent with those of the present research.

Research findings suggested that pre-service teachers also attributed negative meanings to gray, black and white colors. In particular, pre-service teachers attributed both positive and negative meanings to the white 
color. This paves the way for the fact that a single color has series of meanings and interpretations to various people. For instance, De Bortoli and Maroto (2001) stated that the people in China who see white as a sad color as they wear white when mourning, whereas some others in Europe perceive it as purity, virginity, and cleanliness. Besides, pre-service teachers were determined to attribute both negative and positive meanings to the red, yellow, gray, black and brown. Saito (1996) concluded that the color black elicited both negative and positive meanings among Japanese subjects. Çalışkan and Kılıç (2014) also stated that some people perceive black as the color of power in addition to its negative meaning. What is more, considering that the gray color is a mixture of black and white colors and that the positive effects of white and negative effects of black, pre-service teachers may think this color as both positive and negative at the same time. All these may be due to the fact that they are hesitant to the ITs, or they are aware of both advantages and disadvantages while using IT.

Within the scope of the research, the elicited color codes were categorized depending on the meanings attributed to colors by the pre-service teachers; besides, the frequency and percentage values of these categories were calculated. In line with the pre-service teachers' perceptions regarding ITs, 16 conceptual categories were identified. Accordingly, pre-service teachers were identified to mostly mention the category of "ITs as a symbol of wholeness and wide area". Pre-service teachers explained their thoughts by associating them with white, blue, green, purple and all colors since they noted that "ITs" is a combination of knowledge from different disciplines and indicated its content has a wide area. BakaçandÖzen (2016), Bektaş, Nalçacı and Ercoşkun (2009), Maharaj-Sharma et al. (2017) indicated that ITs include a wide range of devices and activities that are apart from one another, but cannot be considered separate in practice.

As a result of the analysis, the pre-service teachers were found to regard ITs as "a symbol of innovation, discovery, creativity and production" mostly by associating it "green" color. Halse (1978) concluded that green symbolizes productivity and fertility, that is, innovation. This result is in line with that of the present research. In addition, the mostly emerging category was noted as ITs as "a symbol of vitality and dynamism", which is associated with the colors of red and yellow. The relevant literature suggested that red and yellow conjure such meanings as dynamism, passion, 
brightness, excitement and passion (Akkın Eğrilmez and Afrashi, 2004; Andrews, 1995). This implied that the pre-service teachers explained the preference of these colors as being vital and dynamic. The other categories were determined as ITs as a symbol of enlightenment, ITs as a symbol of teaching and effectiveness, ITs as a symbol of complex emotions, ITs as a symbol of progress, ITs as a symbol of daily life, ITs as a symbol of tranquility, ITs as a symbol of eternity, ITs as a symbol of pessimism, ITs as a symbol of trust, ITs as a symbol of mystery, ITs as a symbol of neutrality and transparency, ITs as a symbol of harmony and balance, ITs as a symbol of authenticity.

The research findings also revealed the pre-service teachers' feelings about the ITs and the reasons for these feelings. Namely, the majority of the pre-service teachers felt "happy" towards ITs, which were followed by lovely, easy-going and calm. They were found to explain the underlying reasons for having positive feelings towards ITs as facilitating learning and teaching process, being attractive, facilitating daily life, feeling special, ensuring permanent learning, providing creativeness and ensure interaction. This may be due to the fact that being familiar with ITs makes their daily life easier along with enabling them to solve problems in daily life more easily by developing skills such as creative thinking and analytical thinking. A small number of pre-service teachers were identified to prefer the emojis such as afraid, surprised, sad, grin, very sad, ill and sleepy. This may arise from the pre-service teachers' unfamiliarity with the technology in advance or their teachers' attitudes towards the use of technology within the classes. Besides, pre-service teachers did not prefer the emojis such as angry, furious and panic. This indicated that pre-service teachers generally had positive feelings towards "ITs", and their feelings and views towards the ITs are consistent with each other.

\section{Implications and Recommendations}

Based upon the research findings, various recommendations were provided. This research utilized synectic colors and emojis in order to identify the pre-service teachers' feelings towards ITs. Various studies may be conducted to ensure that pre-service teachers relate ITs with different con- 
cepts. It is of great importance to note that this research focused on a deliberately selected group of pre-service teachers in Turkey, and therefore cannot be generalized for all pre-service teachers in the whole country. In fact, it might be that the findings herein are not what obtains in a general sense and that the frequency of pre-service teachers' feelings and views might be far less. Besides, the reasons for the preferences of colors regarding ITs may be more wide-ranging than that suggested here. These speculations may be best clarified through a long term study of similar nature, but it should involve a larger number and a wider cross section of preservice teachers or teachers (science and non-science). Further studies may also employ different data collection tools for color associations in addition to cross-cultural studies.

\section{References}

Adıgüzel, A. (2010). İlköğretim okullarında öğretim teknolojilerinin durumu ve sınıf öğretmenlerinin bu teknolojileri kullanma düzeyleri. Dicle Üniversitesi Ziya Gökalp Ĕ̆itim Fakültesi Dergisi, 15, 1-17.

Akkın, C., Eğrilmez, S. and Afrashi, F. (2004). Renklerin insan davranış ve fizyolojisine etkileri. Türk Oftalmoloji Derneği XXXVI. Kongresi, 33, 274- 282.

Ambrose, G. and Haris. P. (2003). The fundamentals of creative design. Switzerland: Ava. Andrews, T. (1995). Renklerle tedavi. İstanbul: Aritan Yayınclik.

Aslan, A., and Zhu, C. (2015). Pre-service teachers' perceptions of ICT integration in teacher education in Turkey. Turkish Online Journal of Educational TechnologyTOJET, 14(3), 97-110.

Asmall, M., and Dilbaz Sayın, S. S. (2016). The effects of the Synectics Model on vocabulary learning, attitude, and desire to learn English. Asian EFL Journal, 18(3), 41-60.

Babin, B. J., Hardesty, D. M., and Suter, T. A. (2003). Color and shopping intentions: The intervening effect of price fairness and perceived affect. Journal of business research, 56(7), 541-551.

Bakaç, E. and Özen, R. (2016). Öğretmen adaylarının öğretim teknolojileri ve material tasarımı dersine yönelik tutumları, yaratıclık algıları ve öz-yeterlik inançları arasındaki ilişki. Abant İzzet Baysal Üniversitesi Eğitim Fakültesi Dergisi, 16(1), 41-61. 
Bektaş, F., Nalçacı, A. and Erçoşkun, H. (2009). Sınıf öğretmeni adaylarını “"oğretim teknolojileri ve material geliştirme/tasarımı" dersinin kazanımlarına ilişkin görüşleri. Kuramsal Ĕ̆itimbilim Dergisi, 2(2), 19-31.

Commission on Instructional Technology. (1969). To improve learning: A report to the President and the Congress of the United States. Washington, DC: Commission on Instructional Technology.

Creswell, J. W. (2017). Eğitim araştırmalar Nicel ve nitel araştırmanın planlanması, yürütülmesi ve değerlendirilmesi. (Halil Ekşi, çeviri). İstanbul: EDAM.

Creswell, J. W. (2007). Qualitative inquiry and research design: Choosing among five approaches (2nd ed.). Thousand Oaks, CA: Sage.

Creswell, J.W. (2009). Research design, qualitative, quantitative, and mixed methods approaches. Sage publications, Inc. California.

Çalışkan, N. and Kılıç, E. (2014). Farklı kültürlerde ve eğitimsel süreçte renklerin dili. Ahi Evran Üniversitesi Kurşehir Eğitim Fakültesi Dergisi, 15(3), 69-85.

Çekinmez, V. (2010). Farklı kültürlerde renklerin anlamları. Retrieved from http://wwweeen.kso.org.tr/up/download/dokculturandcolor02082010.pdf in 24.01.2020.

De Bortoli, M. and Maroto, J. (2001). Colors across culture: Translating colors in interactive marketing communications. In R. Russow and D. Barbereau (Eds.), Elicit 2001: Proceedings of the European Languages and the Implementation of Communication and Information Technologies (Elicit) conference (p.3-4). UK: Paisley University Language Press.

DeCarlo, C. L. and Rubba, P. A. (1994). What happens during high chemistry laboratory sessions? A descriptive case study of the behaviors exhibited by three teachers and their students. Journal of Science Teacher Education, 5(2), 37-47.

Duran, M. and Bekdemir, M. (2013). Görsel matematik okuryazarllğı özyeterlik algisıly görsel matematik başarısınn değerlendirilmesi. Pegem Eğitim ve Öğretim Dergisi, 3(3), 27-40.

Epps H.H. and Kaya N. (2004) Color matching from memory. In J. J. Caivano, Ed., AIC 2004 Color and Paints, Interim Meeting of the International Color Association, Porto Alegre. Brazil, November 3-5, p.18-21.

Ercan, S. (2010). Fen öğretiminde yaratıc düşünme tekniklerinden sinektik kullanımına yönelik bir eylem araştırması. Yayınlanmamış yüksek lisans tezi. Sakarya Üniversitesi Fen Bilimleri Enstitüsü, Sakarya.

Erdemir, N., Bakırc, H., and Eyduran, E. (2009). Öğretmen adaylarının eğitimde teknolojiyi kullanabilme özgüvenlerinin tespiti. Journal of Turkish Science Education, 6(3), 99-108. 
Pre-service Teachers' Perceptions and Views towards Instructional Technologies: A Study Based upon Synectic Model

Ersoy, A. F. (2016). Fenomenoloji. Eğitimde nitel araştırma desenleri. Ankara: Anı Yayınclik.

Estes, T. H., Mintz, S. L. and Gunter, M. A. (2010). Instruction: A models approach. London: Pearson.

Fraenkel, J. R., Wallen, N. E., and Hyun, H. H. (2012). How to design and evaluate research in education (8th ed.). New York: Mc Graw Hill.

Gedik, N. (2017). Examining the conceptualization of instructional technology in Turkey. Contemporary Educational Technology, 8(1), 76-98.

Gordon, W. J. J. (1961). Synectics: The development of creative capacity. New York: Harper.

Halis, İ. (2002). Instructional technology and material design. Ankara: Nobel Publishing.

Halse, A. O. (1968). The use of color interiors. Mc Graw Hill. http://classics.mit.edu/Aristotle/poetics.mb.txt.

Huchendorf, L. (2007). The effects of color on memory. Journal of Undergraduate Research. Retrieved from http://wwww.uwlax.edu/urc/juronline/PDF/2007/huchendorf.pdf in 24.01.2020

Krippendorff, K. (2004). Content analysis: An introduction to its methodology. Thousand Oaks. Calif.: Sage.

Kurt, S. and Osueke, K. K. (2014). The effects of color on the moods of college students. SAGE Open, 4(1), 1-12.

Kuru, E. and Kuru, O. (2018). Sınıf öğretmeni adaylarının eğitim teknolojisi kavramma ilişkin metaforik alglları. Kahramanmaraş Sütçü İmam Üniversitesi Sosyal Bilimler Dergisi, 16(1), 257-278.

Küçük, S. (2010). Eski Türk kültüründe renk kavramı. Ahmet Yesevi Üniversitesi Bilig Dergisi, 54, 185-210.

Kwallek, N., Woodson, H., Lewis, C. M. and Sales, C. (1997). Impact of three interior color schemes on worker mood and performance relative to individual environmental sensitivity. Color Research and Application: Endorsed by Inter-Society Color Council, The Colour Group (Great Britain), Canadian Society for Color, Color Science Association of Japan, Dutch Society for the Study of Color, The Swedish Colour Centre Foundation, Colour Society of Australia, Centre Français de la Couleur, 22(2), 121-132.

Lee, M. andWinzenried, A. (2009). The use of instructional technology in schools: Lessons to be learned. Aust Council for Ed Research.

Lincoln, Y.S. and Guba, E.G. (1985). Naturalistic inquiry. Newbury Park, CA: Sage.

Lowenthal, P. and Wilson, B. G. (2010). Labels do matter! A critique of AECT's redefinition of the field. Tech Trends, 54(1), 38-46. 
Maharaj-Sharma, R., Sharma, A., and Sharma, A. (2017). Using ICT-based Instructional Technologies to Teach Science: Perspectives from Teachers in Trinidad and Tobago. Australian Journal of Teacher Education, 42(10).

Mazlum, Ö. (2011). Rengin kültürel çağrışımları. Dumluptnar Üniversitesi Sosyal Bilimler Dergisi, 31, 125- 138.

Moustakas, C. (1994). Phenomenological research methods. Thousand Oaks, CA: Sage.

Nolan, V. (2003). Whatever Happened to Synectics? Creativity and Innovation Management,12(1), 24-27.

Patton, M. Q. (2002). Qualitative research and Evaluation methods. 3rd edition. Sage Publications, Inc.

Polat, H., H. (2012). Renk teorisi ve temel yanılgilar. Selçuk Üniversitesi Sosyal Bilimler Enstitüsü Dergisi, 28, 166-173.

Prince, G. M. (1968). The operational mechanism of synectics. The Journal of Creative Behavior, 2(1), 1-13.

Reiser, R. A. and Dempsey, J. V. (Eds.). (2012). Trends and issues in instructional design and technology. Boston: Pearson.

Richey, R. C. and Seels, B. (1994). Defining a field: A case study of the development of the 1994 definition of instructional technology. Educational media and technology yearbook, 20, 2-17.

Saban, A. (2009). Öğretmen adaylarını öğrenci kavramına ilişkin sahip oldukları zihinsel imgeler. Türk Eğitim Bilimleri Dergisi, 7(2), 281-326.

Saettler, P. (1990). The evolution of American educational technology. Connecticut: Information Age Publishing.

Saito, M. (1996). Comparative studies on color preference in Japan and other Asian regions, with special emphasis on the preference for white. Color Research and Application, 21(1), 35-49.

Saraç, H. (2018). Use of instructional technologies by teachers in the educational process: Metaphor analysis study. European Journal of Educational Research, 7(2), 189-202.

Selçuk, G. (2018). Türkçe öğretmen adaylarının öğretim teknolojileri ve material tasarımı dersine ilişkin metaforik algllarının incelenmesi. Akdeniz Eğitim Araștırmalar Dergisi, 12(26), 526-543.

Seligmann, E. R. (2007). Reaching students through synectics: A creative solution. Retrieved from http://www.ellieseligmann.com/essays/synectics seligmann.pdf in 24.01.2020.

Uçar, T. F. (2004). Görsel iletişim ve grafik tasarım. İstanbul: İnkılap Yayınevi. 
Pre-service Teachers' Perceptions and Views towards Instructional Technologies: A Study Based upon Synectic Model

Valdez, P. and Mehrabian, A. (1994). Effects of color on emotions. Journal of experimental psychology: General, 123(4), 394.

Weaver, W. T. and Prince, G. M. (1990). Synectics: Its potential for education. The Phi Delta Kappan, 71(5), 378-388.

Willis, E. M. and Montes, L. S. (2002). Does requiring a technology course in preservice teacher education affect student teacher's technology use in the classroom? Journal of Computing in teacher Education, 18(3), 76-80.

Yıldırım, A. and Şimşek, A. (2005). Sosyal bilimlerde nitel araştırma yöntemleri [Qualitative research methods in the social sciences] (5. Ed.). Ankara: Seçkin Yayınevi.

\section{Citation Information}

Yanpar Yelken, T. and Baysal, S. (2021). Pre-service teachers' perceptions and views towards instructional technologies: A study based upon synectic model. OPUS- International Journal of Society Research, 18(41), 3008-3040. DOI: 10.26466/opus.868978. 